\title{
Marinobacter oulmenensis sp. nov., a moderately halophilic bacterium isolated from brine of a salt concentrator
}

\author{
Karima Kharroub, ${ }^{1,2}$ Margarita Aguilera, ${ }^{1}$ María Luján Jiménez-Pranteda, ${ }^{1}$ \\ Ana González-Paredes, ${ }^{1}$ Alberto Ramos-Cormenzana ${ }^{1}$ \\ and Mercedes Monteoliva-Sánchez ${ }^{1}$ \\ ${ }^{1}$ Departamento de Microbiología, Facultad de Farmacia Campus de Cartuja s/n, 18071 Granada, \\ Spain \\ ${ }^{2}$ Institut de Nutrition de l'Alimentation et des Technologies Agro-Alimentaires, Université Mentouri, \\ Constantine, Algeria
}

Correspondence

Mercedes Monteoliva-Sánchez mmonteol@ugr.es

\begin{abstract}
A Gram-negative, aerobic, moderately halophilic bacterium, designated Set74 ${ }^{\top}$, was isolated from brine of a salt concentrator at Ain Oulmene, Algeria. The strain grew optimally at $37-40{ }^{\circ} \mathrm{C}$, at $\mathrm{pH}$ 6.5-7.0 and with 5-7.5\% (w/v) NaCl and used various organic compounds as sole carbon, nitrogen and energy sources. Ubiquinone 9 (Q-9) was the major lipoquinone. The main cellular fatty acids were $\mathrm{C}_{16: 0}, \mathrm{C}_{18: 1} \omega 9 c$, summed feature 7 (ECL 18.846; $\mathrm{C}_{19: 0}$ cyclo $\omega 10 \mathrm{c}$ and/or $\left.\mathrm{C}_{19: 1} \omega 6 c\right), \mathrm{C}_{12: 0} 3-\mathrm{OH}, \mathrm{C}_{16: 1} \omega 9 c, \mathrm{C}_{18: 0}$ and $\mathrm{C}_{12: 0}$. The major polar lipids were phosphatidylglycerol, diphosphatidylglycerol and phosphatidylethanolamine. The $\mathrm{G}+\mathrm{C}$ content of the genomic DNA was $57.4 \mathrm{~mol} \%$. The $16 \mathrm{~S}$ rRNA gene sequence analysis indicated that strain Set74 ${ }^{\top}$ was a member of the genus Marinobacter. The closest relatives of strain Set74 ${ }^{\top}$ were Marinobacter santoriniensis NKSG ${ }^{\top}$ (97.5\% 16S rRNA gene sequence similarity) and Marinobacter koreensis DD-M3 ${ }^{\top}(97.4 \%)$. DNA-DNA relatedness between strain $\mathrm{Set}^{\top} 4^{\top}$ and $M$. santoriniensis DSM $21262^{\top}$ and $M$. koreensis DSM $17924^{\top}$ was 45 and $37 \%$, respectively. On the basis of the phenotypic, chemotaxonomic and phylogenetic features, a novel species, Marinobacter oulmenensis sp. nov., is proposed. The type strain is Set74 ${ }^{\top}$ (=CECT $7499^{\top}$ $=$ DSM 22359 ${ }^{\top}$.
\end{abstract}

The family Alteromonadaceae was created by Ivanova \& Mikhailov (2001) to accommodate an assemblage of marine Gram-negative, chemoheterotrophic, straight or curved rods. Members of this group include the genera Aestuariibacter, Agarivorans, Aliagarivorans, Alishewanella, Alteromonas, Bowmanella, Glaciecola, Haliea, Marinimicrobium, Marinobacter, Marinobacterium, Melitea, Microbulbifer, Saccharophagus and Salinimonas (Baumann et al., 1972; Bowman et al., 1998; Ekborg et al., 2005; Gauthier et al., 1992; González et al., 1997; Jean et al., 2006, 2009; Jeon et al., 2005; Kurahashi \& Yokota, 2004; Lim et al., 2006; Urios et al., 2008a, b; Vogel et al., 2000; Yi et al., 2004). The genus Marinobacter was proposed by Gauthier et al. (1992) with the type species Marinobacter hydrocarbonoclasticus. Members of this genus can be found in different habitats, including marine environments, hypersaline lakes, saline

The GenBank/EMBL/DDBJ accession number for the $16 \mathrm{~S}$ rRNA gene sequence of strain Set74 ${ }^{\top}$ is FJ897726.

A supplementary figure is available with the online version of this paper. soils and hydrothermal sediments (Martín et al., 2003; Yoon et al., 2004; Handley et al., 2009; Aguilera et al., 2009).

A strain, designated Set $74^{\mathrm{T}}$, was obtained from brine samples collected from the Ain Oulmene salt concentrator $\left(35^{\circ} 55^{\prime} 23^{\prime \prime} \mathrm{N} 5^{\circ} 17^{\prime} 36^{\prime \prime} \mathrm{E}\right)$ in north-eastern Algeria. Isolation was performed in $\mathrm{MH}$ medium (containing per litre distilled water: $1 \mathrm{~g}$ glucose, $5 \mathrm{~g}$ proteose peptone, $5 \mathrm{~g}$ yeast extract) and supplemented with $7.5 \%(\mathrm{w} / \mathrm{v})$ total salts. The total salts stock solution was prepared at $30 \%$ $(\mathrm{w} / \mathrm{v})$ as described by Subov (1931) (per litre distilled water: $234 \mathrm{~g} \mathrm{NaCl}, 42 \mathrm{~g} \mathrm{MgCl}_{2} \cdot 6 \mathrm{H}_{2} \mathrm{O}, 60 \mathrm{~g} \mathrm{MgSO}_{4} \cdot 7 \mathrm{H}_{2} \mathrm{O}$, $1 \mathrm{~g} \mathrm{CaCl} 2.2 \mathrm{H}_{2} \mathrm{O}, 6 \mathrm{~g} \mathrm{KCl}, 0.2 \mathrm{~g} \mathrm{NaHCO}_{3}, 0.7 \mathrm{~g} \mathrm{NaBr}$, $0.005 \mathrm{~g} \mathrm{FeCl}_{3}$ ). The medium was adjusted to $\mathrm{pH} 7.0$ with $\mathrm{NaOH}$ and the medium was solidified with $2.0 \%$ agar (Difco). Incubation was at $37{ }^{\circ} \mathrm{C}$ and a single colony was streaked at least three times on $\mathrm{MH}$ agar to obtain a pure culture. Unless otherwise stated, MH medium was routinely used for cultivation and phenotypic analysis.

Cellular morphology was examined by transmission electron microscopy as described previously (Kharroub 
et al., 2006). Gram staining was performed using a Gram stain kit (Sigma). Growth was tested with 0, 0.5, 1, 3, 5, 7.5, 10,15 and $20 \%(\mathrm{w} / \mathrm{v}) \mathrm{NaCl}$, at $\mathrm{pH} 5.0-10.0$ and at 10,15 , $20,25,30,37,40,45$ and $50{ }^{\circ} \mathrm{C}$. Tests for catalase, oxidase and hydrolysis of aesculin, DNA, gelatin, starch and Tween 80 were conducted according to the methods of Smibert \& Krieg (1981). Growth on MacConkey agar supplemented with $7.5 \%(\mathrm{w} / \mathrm{v}) \mathrm{NaCl}$ was assessed. Tyrosine hydrolysis was revealed by clear zones on medium containing $5 \mathrm{~g}$ L-tyrosine $1^{-1}$. Pigment production was also determined. Simmons' citrate test and $\beta$-galactosidase, arginine dihydrolase, lysine decarboxylase and ornithine decarboxylase activities were tested according to the procedure of Larpent \& Larpent-Gourgaud (1985) with medium supplemented with $7.5 \%(\mathrm{w} / \mathrm{v}) \mathrm{NaCl}$. Urea hydrolysis and indole production were assessed as described by Ventosa et al. (1982). Respiration of nitrate and nitrite, oxidation and fermentation of glucose and acid production from and utilization of organic compounds as sole sources of carbon or nitrogen and energy were determined as described by Mata et al. (2002). Sensitivity to antibiotics was determined using standard disc assays. Analysis of isoprenoid quinones, fatty acid methyl ester profiles and polar lipids was carried out by the DSMZ Identification Service (Braunschweig, Germany).

Genomic DNA was extracted according to Marmur (1961). The 16S rRNA gene of strain Set74 ${ }^{\mathrm{T}}$ was amplified by PCR using primers as described by Saiki et al. (1988). Identification of phylogenetic neighbours and calculation of pairwise sequence similarities were carried out using a BLAST search of sequences in GenBank (Altschul et al., 1997). Multiple sequence alignments were performed using Clustal w version 1.8 (Thompson et al., 1994). Phylogenetic trees were constructed using the neighbour-joining (Saitou \& Nei, 1987) and maximum-parsimony (Fitch, 1971) methods in the MEGA4 package (Tamura et al., 2007). The resultant tree topologies were evaluated by the bootstrap resampling method of Felsenstein (1985) with 1000 replicates.

Genomic DNA G + C content was determined from the mid-point value $\left(T_{\mathrm{m}}\right)$ of the thermal denaturation profile (Marmur \& Doty, 1962). DNA-DNA hybridization studies were performed using the non-radioactive method described by Ziemke et al. (1998). DNA was double-labelled using DIG-11-dUTP and biotin-16-dUTP (Boehringer Mannheim). The labelling reaction was carried out using the Boehringer Mannheim nick-translation kit (Roche Applied Science).

Cells of strain Set $74^{\mathrm{T}}$ were Gram-staining-negative motile rods. Colonies on $\mathrm{MH}$ medium were cream, small, circular, smooth and $2-3 \mathrm{~mm}$ in diameter after incubation for 3 days at $37^{\circ} \mathrm{C}$. Strain Set $74^{\mathrm{T}}$ grew in media containing $1-15 \%(w / v) ~ N a C l$ (optimum $5-7.5 \% \mathrm{NaCl}$ ), at $\mathrm{pH} 5.5-$ 9.0 (optimum pH 6.5-7.0) and at $30-45{ }^{\circ} \mathrm{C}$ (optimum $37-$ $40{ }^{\circ} \mathrm{C}$ ). The detailed phenotypic features of strain Set $74^{\mathrm{T}}$ are presented in the species description and Table 1.
Table 1. Differential characteristics of strain Set $74^{\top}$ and type strains of closely related species of the genus Marinobacter

Strains: 1 , Marinobacter oulmenensis sp. nov. Set $74^{\mathrm{T}}$; 2 , M. santoriniensis DSM $21262^{\mathrm{T}}$; 3, M. koreensis DSM $17924^{\mathrm{T}}$. Data were obtained in this study unless indicated. All strains have rod-shaped cells and are positive for motility, catalase, oxidase and utilization of acetate. All strains are negative for indole production, arginine dihydrolase, glucose fermentation, hydrolysis of aesculin and gelatin and assimilation of glucose and arabinose.

\begin{tabular}{|c|c|c|c|}
\hline Characteristic & 1 & 2 & 3 \\
\hline \multicolumn{4}{|l|}{$\begin{array}{l}\mathrm{NaCl} \text { concentration for growth } \\
(\%, w / v)\end{array}$} \\
\hline Range & $1-15$ & $0.5-16$ & $0.5-20$ \\
\hline Optimum & $5-7.5$ & $5-10$ & $3-8$ \\
\hline \multicolumn{4}{|l|}{$\mathrm{pH}$ for growth } \\
\hline Range & $5.5-9$ & $5.5-9$ & $5-9$ \\
\hline Optimum & $6.5-7$ & $7-8$ & $6-8$ \\
\hline \multicolumn{4}{|l|}{ Temperature for growth $\left({ }^{\circ} \mathrm{C}\right)$} \\
\hline Range & $30-45$ & $25-45$ & $10-45$ \\
\hline Optimum & $37-40$ & 35 & 28 \\
\hline Reduction of nitrate to nitrite & - & + & + \\
\hline Hydrolysis of Tween 80 & - & - & + \\
\hline \multicolumn{4}{|l|}{ Enzyme activities } \\
\hline$\beta$-Galactosidase & + & - & - \\
\hline Urease & - & + & - \\
\hline \multicolumn{4}{|l|}{ Utilization of: } \\
\hline D-Mannitol & + & - & - \\
\hline Citrate & + & - & - \\
\hline Phenylacetic acid & - & + & + \\
\hline Lactate & - & + & + \\
\hline Succinate & + & + & - \\
\hline DNA G $+\mathrm{C}$ content $(\mathrm{mol} \%)$ & 57.4 & $58.1^{a_{\star}}$ & $54.1^{b}$ \\
\hline
\end{tabular}

${ }^{\star}$ Data taken from: a, Handley et al. (2009); b, Kim et al. (2006).

The predominant quinone of strain Set $74^{\mathrm{T}}$ was ubiquinone Q-9; a small amount $(4 \%)$ of Q-8 was also present. The fatty acid profile of strain Set $74^{\mathrm{T}}$ contained saturated and unsaturated straight-chain fatty acids. The major fatty acids were $\mathrm{C}_{16: 0}$ (29\% of total fatty acids), $\mathrm{C}_{18: 1} \omega 9 c(19.6 \%)$, $\mathrm{C}_{12: 0} 3-\mathrm{OH}(9.4 \%), \mathrm{C}_{16: 1} \omega 9 c(8.6 \%), \mathrm{C}_{18: 0}(7.2 \%)$ and $\mathrm{C}_{12: 0}(6.2 \%)$. These fatty acids are also predominant components of other members of the genus Marinobacter (Martín et al., 2003; Yoon et al., 2004; Romanenko et al., 2005; Antunes et al., 2007). Additionally, strain Set $74^{\mathrm{T}}$ contained summed feature 7 (ECL 18.846, $\mathrm{C}_{19: 0}$ cyclo $\omega 10 \mathrm{c}$ and/or $\mathrm{C}_{19: 1} \omega 6 c ; 12.6 \%$ ), which was also reported for the type strains of Marinobacter lutaoensis, Marinobacter bryozoorum and Marinobacter segnicrescens (Shieh et al., 2003; Romanenko et al., 2005; Guo et al., 2007). The polar lipids of strain Set $74^{\mathrm{T}}$ were phosphatidylglycerol, diphosphatidylglycerol and phosphatidylethanolamine, which are reported to predominate in $M$. segnicrescens, Marinobacter excellens and Marinobacter szutsaonensis (Gorshkova et al., 2003; Guo et al., 2007; Wang et al., 
2009). The isolate was also shown to possess two unknown phospholipids and two unknown phosphoglycolipids.

The 16S rRNA gene sequence of strain Set74 ${ }^{\mathrm{T}}$ (1464 nt) was found to be related to those of members of the Gammaproteobacteria and the strain shared a close phylogenetic relationship with members of the genus Marinobacter (Fig. 1), exhibiting highest sequence similarity with Marinobacter santoriniensis NKSG1 ${ }^{\mathrm{T}}$ (97.5\% 16S rRNA gene sequence similarity) and M. koreensis DD-M3 ${ }^{\mathrm{T}}(97.4 \%)$. A phylogenetic tree based on maximum-parsimony analysis of $16 \mathrm{~S}$ rRNA gene sequences is shown in Supplementary Fig. S1 (available in IJSEM Online).

The DNA G $+\mathrm{C}$ content of strain Set $74^{\mathrm{T}}$ was $57.4 \mathrm{~mol} \%$ $\left(T_{\mathrm{m}}\right)$. DNA-DNA relatedness between strain Set $74^{\mathrm{T}}$ and its closest phylogenetic neighbours, $M$. santoriniensis DSM $21262^{\mathrm{T}}$ and Marinobacter koreensis DSM $17924^{\mathrm{T}}$, was 45 and $37 \%$, respectively.

The phenotypic, chemotaxonomic and genotypic data presented above support the assignment of strain Set $74^{\mathrm{T}}$ to a novel species, for which the name Marinobacter oulmenensis sp. nov. is proposed.

\section{Description of Marinobacter oulmenensis sp. nov.}

Marinobacter oulmenensis (oul.me.nen'sis. N.L. masc. adj. oulmenensis belonging to Ain Oulmene salt concentrator, where the species was first isolated).

Cells are Gram-negative, non-spore-forming, motile rods, $0.3-0.5 \mu \mathrm{m}$ wide and 1.6-3.0 $\mu \mathrm{m}$ long. Colonies are cream, small, circular and smooth and $2-3 \mathrm{~mm}$ in diameter after growth on $\mathrm{MH}$ medium containing $7.5 \%(\mathrm{w} / \mathrm{v}) \mathrm{NaCl}$ for 3 days at $37{ }^{\circ} \mathrm{C}$. Moderately halophilic and capable of growth with 1-15\% (w/v) $\mathrm{NaCl}$ (optimum 5-7.5\%, w/v, $\mathrm{NaCl}$ ). Grows at $30-45{ }^{\circ} \mathrm{C}$ (optimum $37-40{ }^{\circ} \mathrm{C}$ ) and at
pH 5.5-9.0 (optimum pH 6.5-7.0). Catalase and oxidase are produced. Aesculin, DNA, gelatin, starch and Tween 80 are not hydrolysed. Indole is not produced. Grows on MacConkey agar and hydrolyses tyrosine with production of pigment. Positive for $\beta$-galactosidase, but negative for urease, arginine dihydrolase, lysine decarboxylase, ornithine decarboxylase and glucose fermentation. Positive for Simmons' citrate test, but does not reduce nitrate or nitrite and negative for respiration of nitrate and nitrite. The following substrates are utilized for growth: D-mannitol, dulcitol, glycerol, acetate, malate, malonate, succinate, oxalate, formate, fumarate, D-glucuronic acid and arginine. Does not utilize D-glucose, D-fructose, D-galactose, cellobiose, L-arabinose, D-mannose, raffinose, sucrose, D-xylose, adonitol, glycerol, benzoate, phenylacetic acid, DL-lactate, L-cysteine, L-lysine, L-methionine, L-alanine, L-tyrosine, L-tryptophan, L-glycine, L-asparagine or L-glutamate. Acid is produced from D-mannitol and dulcitol, but not from D-glucose, D-fructose, D-galactose, cellobiose, L-arabinose, raffinose, D-mannose, sucrose, D-xylose, glycerol or adonitol. The type strain is sensitive to ( $\mu \mathrm{g}$ per disc unless otherwise stated) chloramphenicol (30), kanamycin (30), penicillin $\mathrm{G}(10 \mathrm{U})$, gentamicin (10) and erythromycin (15), but resistant to ampicillin (10), clindamycin (2 U) and novobiocin (30). The predominant isoprenoid quinone is Q-9; a small amount of Q-8 is present. The major fatty acids are $\mathrm{C}_{16: 0}, \mathrm{C}_{18: 1} \omega 9 c$, summed feature $7\left(\mathrm{C}_{19: 0}\right.$ cyclo $\omega 10 c$ and/or $\left.\mathrm{C}_{19: 1} \omega 6 c\right), \mathrm{C}_{12: 0} 3-\mathrm{OH}, \mathrm{C}_{16: 1} \omega 9 c, \mathrm{C}_{18: 0}$ and $\mathrm{C}_{12: 0}$. The polar lipids are phosphatidylglycerol, diphosphatidylglycerol, phosphatidylethanolamine and unknown phospholipids and phosphoglycolipids. The DNA G $+\mathrm{C}$ content of the type strain is $57.4 \mathrm{~mol} \%\left(T_{\mathrm{m}}\right)$.

The type strain is Set74 ${ }^{\mathrm{T}}\left(=\mathrm{CECT} 7499^{\mathrm{T}}=\mathrm{DSM} 22359^{\mathrm{T}}\right)$, which was isolated from brine of a salt concentrator at Ain Oulmene, Algeria.

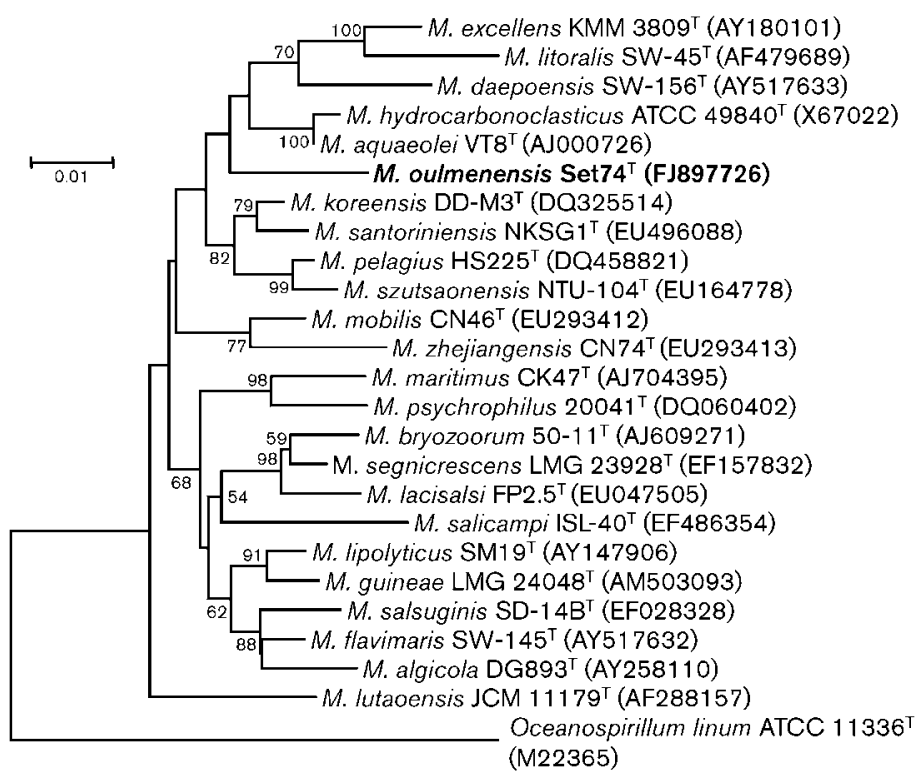

Fig. 1. Neighbour-joining phylogenetic tree based on 16S RNA gene sequences, showing the relationship of strain Set74 ${ }^{\top}$ with other members of the genus Marinobacter. Bootstrap values $(>50 \%)$ based on 1000 replicates are shown at branch nodes. Oceanospirillum linum ATCC $11336^{\top}$ was used as an outgroup. Bar, 1 substitution per 100 nucleotide positions. 


\section{Acknowledgements}

We would like to thank Susanne Verbag at the DSMZ for performing analyses of polar lipids and fatty acids. This study was supported by grants from the Agencia Española de Cooperación Internacional, Spain (project number A/9572/07), and the Junta de Andalucía, Spain (project number BIO-190), and support from the Algerian Ministry of Higher Education and Scientific Research.

\section{References}

Aguilera, M., Jiménez-Pranteda, M. L., Kharroub, K., GonzálezParedes, A., Durban, J. J., Russell, N. J., Ramos-Cormenzana, A. \& Monteoliva-Sánchez, M. (2009). Marinobacter lacisalsi sp. nov., a moderately halophilic bacterium isolated from the saline-wetland wildfowl reserve Fuente de Piedra in southern Spain. Int J Syst Evol Microbiol 59, 1691-1695

Altschul, S. F., Madden, T. L., Schäffer, A. A., Zhang, J., Zhang, Z. Miller, W. \& Lipman, D. J. (1997). Gapped BLAST and PSI-BLAST: a new generation of protein database search programs. Nucleic Acids Res 25, 3389-3402.

Antunes, A., França, L., Rainey, F. A., Huber, R., Nobre, M. F., Edwards, K. J. \& da Costa, M. S. (2007). Marinobacter salsuginis sp. nov., isolated from the brine-seawater interface of the Shaban Deep, Red Sea. Int J Syst Evol Microbiol 57, 1035-1040.

Baumann, L., Baumann, P., Mandel, M. \& Allen, R. D. (1972), Taxonomy of aerobic marine eubacteria. J Bacteriol 110, 402-429.

Bowman, J. P., McCammon, S. A., Brown, J. L. \& McMeekin, T. A. (1998). Glaciecola punicea gen. nov., sp. nov. and Glaciecola pallidula gen. nov., sp. nov.: psychrophilic bacteria from Antarctic sea-ice habitats. Int J Syst Bacteriol 48, 1213-1222.

Ekborg, N. A., Gonzalez, J. M., Howard, M. B., Taylor, L. E., Hutcheson, S. W. \& Weiner, R. M. (2005). Saccharophagus degradans gen. nov., sp. nov., a versatile marine degrader of complex polysaccharides. Int J Syst Evol Microbiol 55, 1545-1549.

Felsenstein, J. (1985). Confidence limits on phylogenies: an approach using the bootstrap. Evolution 39, 783-791.

Fitch, W. (1971). Toward defining the course of evolution: minimum change for a specific tree topology. Syst Zool 20, 406-416.

Gauthier, M. J., Lafay, B., Christen, R., Fernandez, L., Acquaviva, M., Bonin, P. \& Bertrand, J.-C. (1992). Marinobacter hydrocarbonoclasticus gen. nov., sp. nov., a new extremely halotolerant, hydrocarbondegrading marine bacterium. Int J Syst Bacteriol 42, 568-576.

González, J. M., Mayer, F., Moran, M. A., Hodson, R. E. \& Whitman, W. B. (1997). Microbulbifer hydrolyticus gen. nov., sp. nov., and Marinobacterium georgiense gen. nov., sp. nov., two marine bacteria from a lignin-rich pulp mill waste enrichment community. Int J Syst Bacteriol 47, 369-376.

Gorshkova, N. M., Ivanova, E. P., Sergeev, A. F., Zhukova, N. V., Alexeeva, Y., Wright, J. P., Nicolau, D. V., Mikhailov, V. V. \& Christen, R. (2003). Marinobacter excellens sp. nov., isolated from sediments of the Sea of Japan. Int J Syst Evol Microbiol 53, 2073-2078.

Guo, B., Gu, J., Ye, Y.-G., Tang, Y.-Q., Kida, K. \& Wu, X.-L. (2007). Marinobacter segnicrescens sp. nov., a moderate halophile isolated from benthic sediment of the South China Sea. Int J Syst Evol Microbiol 57, 1970-1974.

Handley, K. M., Héry, M. \& Lloyd, J. R. (2009). Marinobacter santoriniensis sp. nov., an arsenate-respiring and arsenite-oxidizing bacterium isolated from hydrothermal sediment. Int J Syst Evol Microbiol 59, 886-892.

Ivanova, E. P. \& Mikhailov, V. V. (2001). A new family, Alteromonadaceae fam. nov., including marina proteobacteria of the genera Alteromonas, Pseudoalteromonas, Idiomarina and Colwellia. Microbiology (English translation of Mikrobiologiia) 70, 10-17.

Jean, W. D., Chen, J.-S., Lin, Y.-T. \& Shieh, W. Y. (2006). Bowmanella denitrificans gen. nov., sp. nov., a denitrifying bacterium isolated from seawater from An-Ping Harbour, Taiwan. Int J Syst Evol Microbiol 56, 2463-2467.

Jean, W. D., Huang, S. P., Liu, T. Y., Chen, J.-S. \& Shieh, W. Y. (2009). Aliagarivorans marinus gen. nov., sp. nov. and Aliagarivorans taiwanensis sp. nov., facultatively anaerobic marine bacteria capable of agar degradation. Int J Syst Evol Microbiol 59, 1880-1887.

Jeon, C. O., Lim, J.-M., Park, D.-J. \& Kim, C.-J. (2005). Salinimonas chungwhensis gen. nov., sp. nov., a moderately halophilic bacterium from a solar saltern in Korea. Int J Syst Evol Microbiol 55, 239-243.

Kharroub, K., Aguilera, M., Quesada, T., Morillo, J. A., RamosCormenzana, A., Boulharouf, A. \& Monteoliva-Sánchez, M. (2006). Salicola salis sp. nov., an extremely halophilic bacterium isolated from Ezzemoul sabkha in Algeria. Int J Syst Evol Microbiol 56, 2647-2652.

Kim, B.-Y., Weon, H.-Y., Yoo, S.-H., Kim, J.-S., Kwon, S.-W., Stackebrandt, E. \& Go, S.-J. (2006). Marinobacter koreensis sp. nov., isolated from sea sand in Korea. Int J Syst Evol Microbiol 56, 2653-2656.

Kurahashi, M. \& Yokota, A. (2004). Agarivorans albus gen. nov., sp. nov., a $\gamma$-proteobacterium isolated from marine animals. Int J Syst Evol Microbiol 54, 693-697.

Larpent, J.-P. \& Larpent-Gourgaud, M. (1985). Manuel Pratique de Microbiologie. Paris: Hermann (in French).

Lim, J.-M., Jeon, C. O., Lee, J.-C., Song, S.-M., Kim, K.-Y. \& Kim, C.-J. (2006). Marinimicrobium koreense gen. nov., sp. nov. and Marinimicrobium agarilyticum sp. nov., novel moderately halotolerant bacteria isolated from tidal flat sediment in Korea. Int J Syst Evol Microbiol 56, 653-657.

Marmur, J. (1961). A procedure for the isolation of deoxyribonucleic acid from microorganisms. J Mol Biol 3, 208-216.

Marmur, J. \& Doty, P. (1962). Determination of the base composition of deoxyribonucleic acid from its thermal denaturation temperature. J Mol Biol 5, 109-118.

Martín, S., Márquez, M. C., Sánchez-Porro, C., Mellado, E., Arahal, D. R. \& Ventosa, A. (2003). Marinobacter lipolyticus sp. nov., a novel moderate halophile with lipolytic activity. Int J Syst Evol Microbiol 53, 1383-1387.

Mata, J. A., Martínez-Cánovas, J., Quesada, E. \& Béjar, V. (2002). A detailed phenotypic characterisation of the type strains of Halomonas species. Syst Appl Microbiol 25, 360-375.

Romanenko, L. A., Schumann, P., Rohde, M., Zhukova, N. V., Mikhailov, V. V. \& Stackebrandt, E. (2005). Marinobacter bryozoorum sp. nov. and Marinobacter sediminum sp. nov., novel bacteria from the marine environment. Int J Syst Evol Microbiol 55, 143-148.

Saiki, R. K., Gelfand, D. H., Stoffel, S., Scharf, S. J., Higuchi, R., Horn, G. T., Mullis, K. B. \& Erlich, H. A. (1988). Primer-directed enzymatic amplification of DNA with a thermostable DNA polymerase. Science 239, 487-491.

Saitou, N. \& Nei, M. (1987). The neighbor-joining method: a new method for reconstructing phylogenetic trees. Mol Biol Evol 4, 406-425.

Shieh, W. Y., Jean, W. D., Lin, Y. T. \& Tseng, M. (2003). Marinobacter lutaoensis sp. nov., a thermotolerant marine bacterium isolated from a coastal hot spring in Lutao, Taiwan. Can J Microbiol 49, 244-252.

Smibert, R. M. \& Krieg, N. R. (1981). General characterization. In Manual of Methods for General Bacteriology, pp. 409-443. Edited by P. Gerhardt, R. G. E. Murray, R. N. Costilow, E. D. Nester, W. A. Wood, N. R. Krieg \& G. B. Phillips. Washington, DC: American Society for Microbiology. 
Subov, N. N. (1931). Oceanographical Tables. Moscow: USSR Oceanographic Institute Hydrometeorological Commission (in Russian).

Tamura, K., Dudley, J., Nei, M. \& Kumar, S. (2007). MEGA4: molecular evolutionary genetics analysis (MEGA) software version 4.0. Mol Biol Evol 24, 1596-1599.

Thompson, J. D., Higgins, D. G. \& Gibson, T. J. (1994). CLUSTAL W: improving the sensitivity of progressive multiple sequence alignment through sequence weighting, position-specific gap penalties and weight matrix choice. Nucleic Acids Res 22, 4673-4680.

Urios, L., Intertaglia, L., Lesongeur, F. \& Lebaron, P. (2008a). Haliea salexigens gen. nov., sp. nov., a member of the Gammaproteobacteria from the Mediterranean Sea. Int J Syst Evol Microbiol 58, 1233-1237.

Urios, L., Agogué, H., Intertaglia, L., Lesongeur, F. \& Lebaron, P. (2008b). Melitea salexigens gen. nov., sp. nov., a gammaproteobacterium from the Mediterranean Sea. Int J Syst Evol Microbiol 58, 2479 2483.

Ventosa, A., Quesada, E., Rodriguez-Valera, F., Ruiz-Berraquero, F. \& Ramos-Cormenzana, A. (1982). Numerical taxonomy of moderately halophilic Gram-negative rods. J Gen Microbiol 128, 1959-1968.

Vogel, B. F., Venkateswaran, K., Christensen, H., Falsen, E., Christiansen, G. \& Gram, L. (2000). Polyphasic taxonomic approach in the description of Alishewanella fetalis gen. nov., sp. nov., isolated from a human foetus. Int J Syst Evol Microbiol 50, 1133-1142.

Wang, C.-Y., Ng, C.-C., Tzeng, W.-S. \& Shyu, Y.-T. (2009). Marinobacter szutsaonensis sp. nov., isolated from a solar saltern. Int J Syst Evol Microbiol 59, 2605-2609.

Yi, H., Bae, K. S. \& Chun, J. (2004). Aestuariibacter salexigens gen. nov., sp. nov. and Aestuariibacter halophilus sp. nov., isolated from tidal flat sediment, and emended description of Alteromonas macleodii. Int J Syst Evol Microbiol 54, 571-576.

Yoon, J.-H., Yeo, S.-H., Kim, I.-G. \& Oh, T.-K. (2004). Marinobacter flavimaris sp. nov. and Marinobacter daepoensis sp. nov., slightly halophilic organisms isolated from sea water of the Yellow Sea in Korea. Int J Syst Evol Microbiol 54, 1799-1803.

Ziemke, F., Höfle, M. G., Lalucat, J. \& Rosselló-Mora, R. (1998). Reclassification of Shewanella putrefaciens Owen's genomic group II as Shewanella baltica sp. nov. Int J Syst Bacteriol 48, 179-186. 